\title{
The Comparative Effect of Online Self-Correction, Peer- correction, and Teacher Correction in Descriptive Writing Tasks on Intermediate EFL Learners' Grammar Knowledge The Prospect of Mobile Assisted Language Learning (MALL)
}

\author{
Mojtaba Aghajani*, Mahsa Zoghipour \\ Khatam ol-Anbia University. Tehran. Iran \\ Shahid Madani University of Azarbaijan, Tabriz, Iran \\ Corresponding Author: Mojtaba Aghajani, E-mail: mojtaba_aghajani45@yahoo.com
}

\section{ARTICLE INFO}

Article history

Received: November 14, 2017

Accepted: January 16, 2018

Published: May 01, 2018

Volume: 7 Issue: 3

Advance access: March 2018

Conflicts of interest: None

Funding: None

\begin{abstract}
60 participants of the study were selected based on their scores on the Nelson proficiency test and divided into three Telegram groups comprising a peer-correction, a self-correction and a teachercorrection group, each with 20 students. The pretest was administered to measure the subjects' grammar knowledge. Subsequently, three Telegram groups each with 21 members ( 20 students +1 teacher) were formed. Then during a course of nearly one academic term the grammatical notions were taught by the teacher. The members were required to write on the prompt in about 50 to 70 words and post it on the group. Then, their writings were corrected through self-correction, peercorrection and teacher-correction under the feedback provided by the researcher. The study used a pretest-posttest design to compare the learners' progress after the application of three different types of treatment. One-Way between-groups ANOVA was run to test whether there was any statistically significant difference in grammar knowledge in descriptive writing of intermediate EFL learners' who receive mobile-assisted self-correction, peer-correction and teacher-correction. The researcher also used Post-Hoc Tests to determine the exact difference between correction methods. Online self-correction, peer-correction and teacher-correction were the independent variables and grammar knowledge was the dependent variable. Examining the result of the study prove that significance level between self-correction and teacher-correction was the strongest (sig. $=0.000$ ) but the significance level was a little less strong between peer-correction and teachercorrection whereas no significance was observed between self-correction and peer-correction.
\end{abstract}

Key words: Self-Correction, Peer - Correction, Teacher - Correction, Grammar Knowledge, Mobile Assisted Language Learning (MALL)

\section{INTRODUCTION}

\section{Introduce the Problem}

The advent of digital age has transformed the way people communicated in the last decades. Technology, in the form of social networks (SNs), has been integrated with communication to challenge the way individuals mix one with another (Richardson \& Hessey, 2009). E-learning and M-learning via internet is a by-product of these technologies that had a pronounced influence on education and as result language learning. Writing is an important act of communication and a purposeful means of addressing an audience that represents language through the inscription of signs and symbols (Harmer, 2004). Writing is an important skill that all language learners have to develop because it is more than a means of creating a document. In most languages; writing is a complement to spoken language.In fact, writing is an area which affects the language learning process of many people around the world. "Writing encourages students to be careful on accurate language use and, because they think as they write, it may well provoke language development as they resolve problems which the writing puts into their minds" (Harmer, 1988, p. 31). Weigle (2002) points to the importance of writing and explain that the ability to write proficiently is becoming increasingly significant in our global community, and instruction in writing is thus presuming an increasing role in second language education.

\section{Explore Importance of the Problem}

Celce-Murcia (2001) points out that speaking and writing appropriately is part of communicative competence. In addition, Köhlmyr (2003) argues that TESOL should make great efforts towards accuracy in order to get full compre- 
hensibility. Norris and Ortega's (2000) meta-analysis of 49 studies, found that the effectiveness of grammar teaching is durable. If it is so, then what, how and when should we teach grammar? Köhlmyr (2003) argues that form-focused grammar instruction is very important in language teaching and that feedback of different kinds at different times is vital to help the learner towards language awareness. Celce-Murcia (2001) shows a similar view when arguing that a Focus-onForm approach during communicative interactions is more successful than other methods. The author offers that grammatical form should be introduced within a meaning-based or communicative approach.

Ellis (2006) claims that grammar is best taught to learners who have already acquired some ability to use the language rather than to complete beginners.

\section{LITERATURE REVIEW}

\section{Teaching Writing}

Along with the emergence of post-method era, many efforts have been done to scrutinize the new trends for teaching writing (Graves, 1991; Greenwald, Persky, Campbell, and Mazzeo, 1999; Heller, 1991; Hicks, 1993; Langer, 2001).

These research studies show that if students pass the steps of observation and writing, better process is achieved than the traditional models of writing. Along with earlier research, Hillocks found that teaching model-writing was effective in enhancing the quality of writing than was grammar-teaching. Moreover, positive effects could be seen in sentence combination (Hillocks, 1987). In addition, “A simplistic view of writing would assume that written language is simply the graphic representation of spoken language" (Brown, 2001, p. 335).

Writing is more intricate than this; hence writing pedagogy is important, as Brown states, writing is "as different from speaking as swimming is from walking” (Brown, 2001, p. 335). This is reinforced and developed by Hedge (2005), who states that writing is more than producing accurate and complete sentences and phrases. She state that writing is about guiding students to: "produce whole pieces of communication, to link and develop information, ideas, or arguments for a particular reader or a group of readers..." (p. 10). Hence, effective writing entails several things: a high degree of organization concerning the development and structuring of ideas, information and arguments (Hedge, 2005). Additionally, Hedge mentioned features such as: high level of accuracy, complex grammar devices, careful selection of vocabulary and sentence structures in order to create style, tone and information suitable for the readers of one's written text (Hedge, 2005).

\section{The Social and Cultural Aspect}

The daily life involves all kinds of writing. Weigle (2002) refers to Hayes, and states that "writing is also social because it is a social artifact and is carried out in a social setting. What we write, how we write and who we write to is shaped by social convention and ... social interaction" (p. 19). It should be remembered that the cultural aspect of teaching writing in the EFL classroom is that when it comes to structure and discourse there may be cultural differences. For instance, Brown (2001) brought up Kaplan's study, and claim that English learners have inclinations that originate from their native languages, when it comes to structuring their writing. Weigle (2002) conducted the same study as an example of writing as a cultural phenomenon.

\section{The Cognitive Aspect}

All through the years, numerous researchers have suggested models for writing as processes of cognitive activities.

Weigle (2002) states that research has been conducted in order to "gain insight into the mental activity and decision making process of the writer as he or she carries out a writing task" (p. 22). Furthermore, Weigle wrote that this thread of research shows that writers devote a lot of time planning and editing their work for both content and organization, as well as taking the audience into consideration. Brown (2001) connected writing and thinking in a very plain way: "Written products are often the result of thinking” (p. 335).

\section{Correction}

As the focus of classroom instruction has changed over the past few decades from an emphasis on language forms to functional language within communicative context, the question of the place of error correction or corrective feedback (CF), has become more and more imperative (Brown, 2007). The errors learners commit are not anymore considered as deficiency (Gass and Selinker, 2008), and the corrections teachers provide to students are taken as opportunities for increasing students learning. Moreover, corrective feedback has changed the conventional perspective of the teacher as the heart of the teaching process to more student collaboration in class, which has also led to peer-corrective feedback in language classes as a substitute to teacher corrective feedback. Researchers have found out different answers to practical questions related to the problems such as how, when and who to correct students (Lyster and Ranta, 1997; Surakka, 2007; Rahimi and Dastjerdi, 2012; Taipale, 2012). As observed in different studies, there are various techniques that teachers employ to deal with students' errors in classes. The effectiveness of corrective feedback can depend on different items such as student anxiety (Allwright and Bailey, 1991), or the equivocal nature of some types of correction (Mackey, Gass, and McDonough, 2000), the proficiency level of students and the amount of difference between the student's utterance and the target form (Philp, 2003).

Correction is very important in any ELT class as learners deem correction as a source of progress (Chaudron, 1988, as cited in Celce-Murcia, 2001), but it is the instructor who controls and chooses the most appropriate time for correction, the best sort of that and whether or not to correct. There are types of correction (Brown, 2007; Celce-Murcia, 2001): explicit/direct (Brown, 2007), implicit/indirect (Richards and Schmidt, 2002), peer-correction (Paulston and Bruder, 1976), self-correction (Swain, 1985), repetition, clarifica- 
tion request, meta-linguistic feedback, recast, and elicitation (Brown, 2007).

According to Brown (2007), corrective feedback encompasses responses to learners' produced utterances which fix or attract attention to their errors. In ELT classrooms, when a learner makes a mistake, it might be corrected by the instructor, the learner or others. Generally, the situations where the correction is provided are as follows: (Teacher-correction, Peer-correction, Self-correction)

\section{Language Learning and Technology}

In order to elucidate the course of review for the present research, this part mostly mentions main domestic and overseas studies in the area of technology and language learning. Technology and its upshot on learning has been long topic of debates. Burston (2006) and Mustafa (2001) claims that there is not sufficient proof to prove the effectiveness of technology use in learning. On the contrary, many other researchers (Pusack and Otto, 1997; Alessi and Trollip, 2001; Dexter, 2002) argue against such declarations and supported the use of technology in developing learning processes. Nonetheless, manifestly the increasing speed of technology integration supports its superb function in educational context.

Warschauer and Meskill (2000) gave a concise account of technologies used for every period of language teaching development. They argue that every method of language teaching, unavoidably borrows a type of educational technology. Starting from the grammar-translation onwards, they complemented related technologies for each stage. Table 2.1 is an illustration of their classification.

\section{Mobile Learning (M-Learning)}

\section{Definition}

To have a technology supported learning, m-learning has attached the attention of second language learning and teaching (Sharples, Taylor, and Vavoula, 2005). As Sharples, Taylor, and Vavoula (2005) states through M-learning, the opportunities for learning outside of the classroom and using personal sources for learning are provided. Although many students prefer to be in traditional classroom to learn a second language; m-learning has advantages that can be substituted for formal traditional education (Sharples, Taylor, and Vavoula, 2005).As Kukulska-Hulme (2009) said m-learning refers to the use of tablet PCs, i-Pod, net books, media player, cell phones, and telephone network in learning.

\section{Effectiveness of m-learning in second language learning}

As Kukulska-Hulme and shield (2008) states "Initially developed from computer-assisted language learning (CALL), MALL immediately seized the attention of language education researchers and has been recognized as different from CALL in many respects, due to its "anytime, anywhere principle" (p. 6). Moreover, Kukulska-Hulme (2009) mention that m-learning could help students in terms of their needs for learning, because it can integrate in students' real lives.

In addition to the benefits m-learning has in second language learning, it may improve students' autonomy as Benson (2007) claimed. Through use of mobile in reading classrooms, reading can become more meaningful, manageable, and convenient for the learners (Hansol and Jang, 2013). Abraham (2008) conducted a study, which revealed that computer-mediated glossing had large effect on language learners' incidental vocabulary learning; however, the effect on their reading comprehension was medium. Providing students with high technology is another advantage of MALL. Automatic scrolling, I-frame structure, and large frame size are provided in m-learning (Hansol and Jang, 2013).

\section{Studies on mobile learning}

Lan, Sung, and Chang (2007) use tablet PCs to develop mobile peer assisted language learning. In this study, students read a passage to their classmates through using Skype in their tablets, and their peers assessed their pronunciation and highlighted their errors using mobile. Over a short period of time, it was clear that such a strategy could facilitate peer communication and collaboration to enable students to correct their errors in reading aloud programs.

To check the improvement of students' speaking skills in English, Gromik (2012) conducted a case study in Japan and used cell phone video recordings. In this study, nine participants ranged from 19 to 20 years of age produced a 30 -second video in target language through using their cell phones. The results of pretest and posttest revealed the promotion of students' speaking abilities through a cell phone video project, which took 14 weeks. Moreover, students had positive attitudes toward using their cell phones as tools to talk in English, so cell phone video recording was seen as a useful activity not only to improve students writing and reading but also to develop students speaking skills.

Table 2.1. Classification of technologies in language teaching development (warschauer and Meskill, 2000)

\begin{tabular}{lll}
\hline $\begin{array}{l}\text { Learning } \\
\text { approach }\end{array}$ & Methods & Salient technology \\
\hline & Grammar-translation & Blackboard, overhead projector \\
Behavioristic & Audio-lingual & Audio-tape \\
Cognitive & Communicative language teaching & $\begin{array}{l}\text { Text-recognition software, concordancing software, } \\
\text { telecommunications, and multimedia simulation software }\end{array}$ \\
Socio-cognitive & Communicative language teaching & The internet, WWW \\
\hline
\end{tabular}




\section{METHOD}

\section{Design}

To achieve the objectives of the study, the present study employed a quasi-experimental design with three groups each of which receive a different type of treatment corresponding to online self-correction, peer-correction and teacher correction.

The study used a pretest-posttest design to compare the learners' progress after the application of three different types of treatment. For analyzing the data obtained from the experiment, descriptive and inferential statistics was used. Regarding the data analysis method, the study was quantitative, since it used parametric tests to compare the mean scores of the participants on the grammar test. Online self-correction, peer-correction and teacher-correction were the independent variables and grammar knowledge was the dependent variable.

\section{Participants}

The participants of this study included 60 intermediate EFL learners who were under the instruction of the researcher.

They were selected from the available population of 92 . Participants were learners of six intact classes of a language institute. The inclusion criteria for students to participate in the study were as follows:

Obtaining the required score on the Nelson proficiency test; Access to high-speed internet connection; and giving written consent to be a member on the Telegram groups. The participants of this study comprised 23 male and 37 female EFL learners, between the ages of 16 to 22 years.

\section{Instrumentation}

In order to meet the criteria of the present research according to the research questions, some instruments were used.

\section{Nelson english language proficiency test}

The first instrument is the 50 item Nelson English Language Proficiency Test (section 200 A) (Fowler \& Coe, 1976) which ensured the homogeneity of the language learners. The test consists of cloze passages (a standard cloze passage is a reading comprehension text in which every seventh word is deleted), structure, vocabulary, and reading comprehension in a multiple-choice format.

\section{The multiple-choice grammar test}

The second instrument was a 30-item multiple-choice researcher-made grammar test as the pretest and posttest to measure the subjects' grammar knowledge (See Appendix B). The other instrument was a package of five grammatical notions, together with related prompts extracted from Leech and Svartvik's (1994) a communicative Grammar of English. These grammatical notions include are as follows:

(1) Time, tense and aspect (Present time, past time, The Progressive aspect);

(2) Time-when;

(3) Duration;
(4) Frequency; and

(5) Place, direction and distance (Leech \&Svartvik, 1994, pp. 113-193)

\section{Procedure}

\section{Participant selection}

First, the participants were selected based on their scores on the Nelson proficiency test. Using Cochran's sampling formula; the required sample size for the present study was equal to 60 participants (out of a population of 92 people) with $93 \%$ of confidence. This selection indicated that a sample of 60 participants represents the population of the study with only $7 \%$ of error, i.e. with $93 \%$ of accuracy.

\section{Pretest}

In the next step, the pretest was administered. It consisted of a 30-item multiple-choice researcher-made grammar test to measure the subjects' grammar knowledge at the start of the study.

\section{Grouping}

Afterwards, three Telegram groups including peer-correction, self-correction and teacher-correction, each with 21 members (20 students +1 teacher) were formed, once the participants gave written consent to be a member of the groups.

\section{Treatment}

Then during a course of nearly one academic term (at least 16 sessions, each about $60-75$ minutes) on a regular basis, the grammatical notions were taught by the teacher. The teacher provided his feedback in all the three groups through direct written messages. Then after the instruction and online practice, a prompt was uploaded by the teacher. The members were required to write on the prompt in about 50 to 70 words (as a meaningful paragraph) within 15 minutes and post it on the group as images of hand-written texts or typed ones. They were required to use, at least once, grammatical structures that had been reviewed. Then, in all of the three groups, their writings were corrected through self-correction, peer-correction and teacher-correction under the feedback provided by the researcher.

\section{Post test}

After the completion of the course, the posttest was administered in a face-to-face classroom and the collected data were tabulated for further analyzed.

\section{DATA ANALYSIS AND DISCUSSION}

\section{Homogeneity Process}

\section{Proficiency test}

In order to have a homogenous study group, the Nelson English Proficiency Test was administered. Table 4.1 shows the descriptive findings of the Nelson Test. 
According to Cochran's sampling formula, the sample size needed for the present study was equal to 60 people (out of a population of 92 people) with $93 \%$ of confidence. This means that a sample of 60 participants represents the population of the study with only $7 \%$ of error, i.e. with $93 \%$ of accuracy. Table 4.2 shows the frequency results of the Nelson English Proficiency Test.

\section{Investigating the Research Question}

In order to test the research hypothesis (H0: There is not any statistically significant difference in grammar knowledge in descriptive writing of intermediate EFL learners, who receive mobile-assisted self-correction, peer-correction and teacher-correction), One-Way between-groups ANOVA was run. In this way, the comparison of the initial pretest and the final posttest results between three correction types (self-correction, peer-correction and teacher-correction) was made possible. The One-Way ANOVA is especially suited when the independent variable is multilevel and categorical whereas the dependent variable is continuous.

The first ANOVA was run to test whether there was any significant difference in grammar knowledge in descriptive writing of intermediate EFL learners who receive mobile-assisted self-correction, peer-correction and teacher-correction at the pretest stage. The results of the analysis, as illustrated in Table 4.3 and Table 4.6, revealed no significant difference among the three participant groups.

Examining the Levene's test for homogeneity of variance (Sig. $=0.865>0.05)$ proved that the assumption of homogeneity of variance had not been violated and that the variance in scores was the same for each of the three groups (self-correction, peer-correction and teacher-correction). As the results indicate, with regard to the Fisher statistic (0.826) and the level of significance $(p=0.443)$, it is concluded that there is no significant difference among the mean scores on the dependent variable for the three groups, and that the correction style has no impact on intermediate EFL learners' grammar knowledge in descriptive writing tasks at pretest stage.

The second ANOVA Statistical procedure was run to test whether there was any significant difference in grammar knowledge in descriptive writing of intermediate EFL learners who received mobile-assisted self- correction, peer-correction and teacher-correction at the posttest stage. The results of the analysis, as illustrated in Table 4.5 and Table 4.6, revealed a significant difference among the three participant groups $(p=0.000)$.

In order to find out which groups outperformed others, it was necessary to run a post hoc comparison among groups. The most commonly used post-hoc tests are Tukey's Honestly Significant Different test (HSD). From among the possible methods of post hoc comparisons, the researcher used the most frequently-used and conservative of all named Tukey's Honestly Significant Different test (HSD). The results of the Tukey's (HSD)test are demonstrated in Table 4.7. The asterisks show that the difference among groups is statistically significant, and the plus or minus signs show which group is superior. The minus means that the second group was better.

The results of the above table demonstrate that signifi- cance level between self-correction and teacher correction was the strongest ( $\mathrm{sig} .=0.000$ ) but the significance level was a little less strong between peer-correction and teacher-correction $(\mathrm{sig}=0.003)$ whereas no significance was observed between self-correction and peer-correction ( $\operatorname{sig}$. $=0.181)$.

\section{CONCLUSION}

\section{Discussion}

The students in self-correction and peer-correction groups outperformed the teacher-correction group. The findings of the present study are all in the same line with the results of some previous studies (Bahrami, 2002; Chandler, 2003; Erfanian, 2002; Lalande, 1982; Lyster, 1998). The results obtained in the mentioned studies revealed that selfcorrection was an effective way of giving feedback. However, the re-

Table 4.1. Descriptive statistics of the nelson English proficiency test

\begin{tabular}{lc}
\hline $\mathbf{N}$ & Valid60 60 Missing 0 \\
\hline Mean & 30.31 \\
Median & 30.00 \\
Mode & 29.00 \\
Standard deviation & 4.12 \\
Variance & 17.00 \\
Minimum & 22.00 \\
Maximum & 39.00 \\
\hline
\end{tabular}

Table 4.2. The frequency results of the nelson English proficiency test

\begin{tabular}{|c|c|c|c|c|}
\hline \multicolumn{5}{|c|}{ Nelson English Proficiency Test } \\
\hline & Frequency & Percent & $\begin{array}{c}\text { Valid } \\
\text { percent }\end{array}$ & $\begin{array}{c}\text { Cumulative } \\
\text { percent }\end{array}$ \\
\hline \multicolumn{5}{|l|}{ Valid } \\
\hline 200 & 1 & 107 & 107 & 1.7 \\
\hline 24.00 & 3 & 5.0 & 5.0 & 6.7 \\
\hline 25.00 & 3 & 5.0 & 5.0 & 11.7 \\
\hline 26.00 & 5 & 8.3 & 8.3 & 20.00 \\
\hline 27.00 & 5 & 8.3 & 8.3 & 28.3 \\
\hline 28.00 & 4 & 6.7 & 6.7 & 35.00 \\
\hline 29.00 & 8 & 13.3 & 13.3 & 48.3 \\
\hline 30.00 & 6 & 10.0 & 10.0 & 58.3 \\
\hline 31.00 & 3 & 5.0 & 5.0 & 63.3 \\
\hline 32.00 & 1 & 6.7 & 6.7 & 70.0 \\
\hline 33.00 & 4 & 1.7 & 1.7 & 71.7 \\
\hline 34.00 & 4 & 6.7 & 6.7 & 78.3 \\
\hline 35.00 & 4 & 6.7 & 6.7 & 85.0 \\
\hline 36.00 & 4 & 6.7 & 6.7 & 91.7 \\
\hline 37.00 & 4 & 6.7 & 6.7 & 98.3 \\
\hline 39.00 & 1 & 1.7 & 1.7 & 100.0 \\
\hline Total & 60 & 100.0 & 100.0 & \\
\hline
\end{tabular}


Table 4.3. The descriptive ANOVA results of difference in grammar knowledge in descriptive writing of intermediate EFL learners who receive mobile-assisted self-correction, peer-correction and teacher-correction at pretest stage

\begin{tabular}{|c|c|c|c|c|c|c|c|c|}
\hline \multicolumn{9}{|c|}{ Descriptives } \\
\hline \multicolumn{9}{|c|}{ Pretest stage } \\
\hline \multicolumn{9}{|c|}{$95 \%$ confidence interval for mean } \\
\hline & $\mathbf{N}$ & Mean & $\begin{array}{l}\text { Standard } \\
\text { deviation }\end{array}$ & Standard Error & Lower bound & Upper bound & Minimum & Maximum \\
\hline Self & 20 & 19.65 & 4.22 & 0.9438 & 17.67 & 21.62 & 15.00 & 31.00 \\
\hline Peer & 20 & 20.65 & 3.57 & 0.7989 & 18.97 & 22.32 & 15.00 & 29.00 \\
\hline Teacher & 20 & 21.20 & 3.77 & 0.8448 & 19.43 & 22.96 & 15.00 & 28.00 \\
\hline Total & 60 & 20.50 & 3.85 & 0.4977 & 19.50 & 21.49 & 15.00 & 31.00 \\
\hline
\end{tabular}

Table 4.4. Test of homogeinity of variances and ANOVA results of the three groups

\begin{tabular}{|c|c|c|c|c|c|}
\hline \multicolumn{6}{|c|}{ Test of homogeinity of variances } \\
\hline \multicolumn{6}{|l|}{ Post-test } \\
\hline Levene statistics & \multicolumn{2}{|c|}{ df1 } & \multicolumn{2}{|l|}{ df 2} & sig. \\
\hline 0.145 & 2 & & 57 & & 0.865 \\
\hline \multicolumn{6}{|c|}{ ANOVA } \\
\hline & $\begin{array}{l}\text { Sum of } \\
\text { squares }\end{array}$ & df & $\begin{array}{c}\text { Mean } \\
\text { Square }\end{array}$ & $\mathbf{F}$ & sig. \\
\hline Between groups & 24.70 & 2 & 12.350 & 0.826 & 0.443 \\
\hline Within groups & 852.300 & 57 & 14.953 & & \\
\hline Total & 877.000 & 59 & & & \\
\hline
\end{tabular}

sults obtained from Yeganehfar's (2000) study disagreed with the afore-mentioned ones as well as the results of the present research. Her results showed that the teacher-correction group outperformed the self-correction group in their writing.

"One possible explanation might be that in self-correction group, the students were directly and actively involved in the process of learning, and this must have brought about a deeper learning.’(Ganji, 2009, p. 133).

The second finding of this study was that the students who did the peer-correction performed better than those who did teacher-correction. This was in line with the results of the studies such as Mendonca and Johnson (1994), where it was found out that peer-correction was an effective method for increasing writing accuracy and performance, just as it proved to be an efficient way of increasing grammatical knowledge of students in the present study. However, it was proved that peer-correction was not as strong as self-correction.

The last comparison to be made was between self-correction and peer-correction groups. As it can be understood from Table 4.10, the best way of correction that can lead to grammatical knowledge increase in the present study is through self-correction, contrary to Ganji's (2009) study where peer-correction turned out to be more effective than self-correction.

As was said before, the findings obtained in the present study do not corresponded with Mendonca and Johnson's
(1994) study in which they concluded that peer-feedback was more effective than self-feedback. An evident conclusion from the present research is that it seems there is a positive correlation between the amount of involvement in the correcting process and the amount of increase in the grammatical knowledge. Both in self-correction and in peer-correction, learners become involved in the learning process, and this was possibly the reason why they were more successful than teacher-correction group. However, the self-correction group proved even more effective because the amount of learning involvement may be the highest in it.

The logical conclusion of the present study is that teacher-correction method exhausts the time and energy of learners and teachers. Self-correction and peer-correction, however, are highly effective in that they help improve the writing performance and grammar knowledge of the learners. These two effective correction techniques are recommended to be adopted both by teachers and the learners in their writing programs. A further outcome of utilizing these two correction techniques is that teachers can train their learners to appreciate revision-related tasks, which can lead to the discovery of development of global approaches to writing and correction of writing.

It also turns out from the present study that the type of feedback provided to the learners can have a noteworthy impact on the writing accuracy. If full peer- or self-correction is exercised in writing classes, and if learners are allowed to deliver their correction feedback experience in the form of conferences to other class members, far more accuracy and much more grammatical knowledge are expected.

The inclination towards self- and peer-correction can bring up the issue of the teaching systems distancing themselves from the traditional methods. Contrary to "learners of most of the Asian countries [that] are taught in traditional settings, where the teacher is considered to possess all the knowledge and students" (Sultana, 2009, p. 17) Iranian EFL learners are experiencing different instruction and correction methodologies.

Teacher evaluation, on the other hand, can sharpen the learner-writers' ability to self-correct errors. In cases where self- or peer-correction seems to be less effective, teachers' identification of learners' errors can help the learners to become well aware of their errors. This can scaffold later self- or peer-correction abilities of the learners.

Self-correction requires noticing from the side of learners Noticing has been defined as when learners "recognize consciously some of their linguistic problems" (Swain, 2005, 
Table 4.5. The descriptive ANOVA results of difference in grammar knowledge in descriptive writing of intermediate EFL learners who receive mobile-assisted self-correction, peer-correction and teacher correction at posttest stage

\begin{tabular}{|c|c|c|c|c|c|c|c|c|}
\hline \multicolumn{9}{|c|}{ Descriptives } \\
\hline \multicolumn{9}{|c|}{ Pretest stage } \\
\hline \multicolumn{9}{|c|}{$95 \%$ confidence interval for mean } \\
\hline & $\mathbf{N}$ & Mean & $\begin{array}{l}\text { Standard } \\
\text { deviation }\end{array}$ & $\begin{array}{c}\text { Standard } \\
\text { Error }\end{array}$ & Lower bound & Upper bound & Minimum & Maximum \\
\hline Self & 20 & 34.05 & 3.546 & 0.7929 & 32.39 & 35.70 & 29.00 & 40.00 \\
\hline Peer & 20 & 32.30 & 2.250 & 0.5031 & 31.24 & 33.35 & 29.00 & 36.00 \\
\hline Teacher & 20 & 28.90 & 3.307 & 0.739 & 27.35 & 30.44 & 25.00 & 36.00 \\
\hline Total & 60 & 31.75 & 3.721 & 0.480 & 30.78 & 32.71 & 25.00 & 40.00 \\
\hline
\end{tabular}

Table 4.6. The ANOVA results of difference in grammar knowledge in descriptive writing of intermediate EFL learners who receive mobile-assisted self-correction, peer-correction and teacher-correction at posttest Stage

\begin{tabular}{lccccc}
\hline \multicolumn{5}{c}{ ANOVA } \\
\hline & Sum of squares & df & Mean Square & F & sig. \\
\hline Between groups & 274.300 & 2 & 137.150 & 0.000 \\
Within groups & 542.950 & 57 & 9525 & \\
Total & 817.250 & 59 & & \\
\hline
\end{tabular}

Table 4.7. The tukey HSD test at 0.05 significance level

\begin{tabular}{l} 
Multiple comparisons \\
\hline Dependent variable: post-test \\
\hline Tukey HSD
\end{tabular}

\section{$95 \%$ confidence interval}

\begin{tabular}{llccccc}
\hline (I) Correction & (J) corection & MeanDifference (I-J) & Standard errror & .sig & Lower bound & Upper bound \\
\hline Self & Peer & 1.75000 & 0.97598 & 0.181 & -0.5986 & 4.0986 \\
& Teacher & $5.15000^{*}$ & 0.97598 & 0.000 & 2.8014 & 7.4986 \\
\multirow{2}{*}{ Peer } & Self & -1.75000 & 97598 & 0.181 & -4.0986 & 0.5986 \\
& Teacher & $3.40000^{*}$ & 97598 & 0.003 & 1.0514 & 5.7486 \\
Teacher & Self & $-5.15000^{*}$ & 0.97598 & 0.000 & -7.4986 & -2.8014 \\
& Peer & $-3.40000^{*}$ & 0.97598 & 0.003 & -5.7486 & -1.0514 \\
\hline
\end{tabular}

*. The mean differenc is significant at the 0.05 level

Table 4.8. Homogeneous subsets

\begin{tabular}{|c|c|c|c|}
\hline \multicolumn{4}{|l|}{ posttest } \\
\hline \multicolumn{4}{|c|}{ Tukey HSD* } \\
\hline \multicolumn{4}{|c|}{ Subset for alpha $=0.05$} \\
\hline Correction & $\mathrm{N}$ & 1 & 2 \\
\hline Teacher & 20 & 28.9000 & \\
\hline Peer & 20 & & 32.3000 \\
\hline Self & 20 & & 34.0500 \\
\hline Sig. & & 1.000 & 0.181 \\
\hline
\end{tabular}

*. Uses harmonic mean sample size $=20.00$

p. 474). The logical result is that self-corrections can lead to the production of modified output, meaning that the learners will improve their writing and grammar.
Implications, applications, and suggestions

\section{Implications for language teaching}

The following implications can be mentioned as a result of the findings of the present study:

1. In peer-correction, students are required to correct each other's errors. The benefit of this approach, among others, is that students' correction of their peers' writing turns into a learning source. The benefits of this approach also include "the possibility that students may learn from others' mistakes. The disadvantages, however, include the fact that students often regard each other's advice with suspicion, considering that they are no more likely to be correct than themselves. Nevertheless, peer correction can provide another avenue for consideration of error, and help to reduce teacher dependence." (Chunhong and Griffiths, 2012, p. 307). 
2. In self-correction method, students become able to examine their own work and correct their own errors. However, the presupposition for this ability is a reasonably high level of proficiency, which is often missing in the case of many EFL students. What is more, a good many of students often lack confidence and willingness to spend time on self-correction because this is regarded as the teacher's job. If students are encouraged to become self-critical, their autonomy will increase. This feature has been shown to be a characteristic of good language learners.

3. As was noted above, correction is often considered to be the teacher's job, a responsibility that is expected by students and by the educational and academic institutions. Teachers are not sure of the value of this area of their work and are discouraged because they face the same errors being repeated again and again, even after many hours of corrective feedback are spent. Since teachers receive a low return on the time they invest in correction job, they most often prefer to play down this aspect of their role. Therefore, self- or peer-correction will be two appropriate substitutes for teacher-correction.

\section{Implications for testing}

Since correction of students' writing works takes away a lot of teachers' time, self- and/or peer-correction approaches will ease the teachers' job and save his/her precious time. Teachers can invest their time on more practical issues that intend to increase the students' grammar and writing ability.

\section{Implications for materials development}

If language learners are given strong motivation via the use of technology, they will inevitably learn a foreign language (Corder, 1974). Corder's words point to the two essential requirements for foreign language learning: motivation which can come through technology use - and language input - which is also fulfilled through technology. Whereas input is certainly the fundamental component for language learning, the amount and degree of learning/teaching challenge are matters of unremitting and prolific research in the SLA/FLA field with straight implications for materials development.

\section{REFERENCES}

Abraham, L. B. (2008). Computer-mediated glosses in second language reading comprehension and vocabulary learning: A meta-analysis. Computer Assisted Language Learning, 21(3), 199-226.

Alessi, S. \& Trollip, S. (2001). Multimedia for learning methods and development ( $3^{\text {rd }}$ Ed.). Massachusetts: Allyn and Bacon.

Allwright, D. \& Bailey, K. M. (1991), Focus on the Language Learner. Cambridge, Cambridge University Press.

Benson, P. (2007). State-of-the-art article: Autonomy in language teaching and learning. Language Teaching,40(1), 21-40.
Brown, H. D. (2001). Teaching by Principles: An Interactive Approach to Language Pedagogy $-2^{\text {nd }}$ Edition. New York: Longman.

Brown, H.D. (2007). Principles of language learning and teaching $\left(5^{\text {th }}\right.$ Ed.). White Plains, NY: Pearson Education.

Burston, J. (2006). Measuring Effectiveness. In Donaldson, R.P. \& Haggstrom, M.A. (Eds.). Changing language education through CALL. London: Routledge.

Celce-Murcia, M. (2001). Teaching English as a second or foreign language ( $3^{\text {rd }}$ Ed.). New York: Heinle \& Heinle.

Chaudron, C. (1988). Second Language Classrooms: Research on Teaching and Learning. New York: Cambridge University Press.

Chunhong, Z. \& Griffiths, C. (2012).Quantitative and Qualitative Perspectives on Individual Differences in Error Correction Preferences. In M.Pawlak (Ed.), New Perspectives on Individual Differences in Language Learning and Teaching, pp. 305-317.

Corder, S. P. (1974). The significance of learners'errors. In J. Richards (Ed.), Error Analysis: Perspectives in Second Language Acquisition. pp. 19-30. London: Longman.

Dexter, S. (2002). ETIPs - Educational technology integration and implementation principles [Online]. In P. Rodgers (Ed.). Designing instruction for technology enhanced learning (pp.56-70). New York: Idea Group Publishing. Retrieved June 10, 2012, from http://www.sdexter.net/ Vitae/papers/etips.pdf

Ellis, R. (2006). Current issues in the teaching of grammar: An SLA perspective. TESOL Quarterly, 40(1), 83-107.

Fowler, W. S., \& Coe, N. (1976). Nelson proficiency tests. London, England: Butler \& Tanner Ltd.

Gass S., \& Selinker L., (2008). Second language acquisition: an introductory course (3rdEdition). Routledge: New York.

Graves, D.H. (1991). Build a literate classroom. Portsmouth, NH: Heinemann.

Greenwald, E.A., Persky, H.R., Campbell, J.R., \& Mazzeo, J. (1999). The NAEP 1998 writing report card for the nation and the states (NCES 1999-462).

Gromik, N (2012). Cell phone video recording feature as a language learning tool: A case study. Computers and education, 58(1), 223-230. http://dx.doi.org/10.1016/j. compedu.2011.06.013

Hansol, L. \& Jang, L. (2013). Implementing glossing in mobile-assisted language learning environments: direction \& outlook. Language learning and technology, 17(3), 6-22.

Harmer, J. (1988a). How to Teach English. London: Person Longman, The Practice of English Language Teaching. $4^{\text {th }}$ ed. London: Pearson Longman, 1988b.

Harmer, J. (2004). How to Teach Writing. Pearson: Longman.

Hedge, T. (2005). Writing. Oxford/New York: Oxford University Press.

Heller, M. (1991).Reading-writing connections: From theory to practice. New York, NY: Longman.

Hicks, J.R. (1993). Let's get serious about teaching children to write. Lanham, MD: University Press.

Hillocks, G. (1987). Synthesis of research on teaching writing. Educational Leadership, 44 (8), 71-82.

Köhlmyr, P. (2003). "To Err is Human." An investigation of grammatical errors in Swedish 16-year-old learners' 
written production in English. Gothenburg: University of Gothenburg, Department of English.

Kukulska-Hulme, A. (2009). Will mobile learning change language learning? ReCALL, 21(2), 157-165.

Kukulska-Hulme, A., \& Shield, L. (2008). An overview of mobile assisted language learning: From content delivery to supported collaboration and interaction. ReCALL, 20(3), 271-289.

Lan, Y.-J., Sung, Y.-T., \& Chang, K.-E. (2007). A mobile-device-supported peer- assisted learning system for collaborative early EFL reading. Language Learning \& Technology, 11(3), 130-151.

Langer, J. (2001). Beating the odds: Teaching middle and high school students to read and write well.

American Educational Research Journal, 38(4), 837-880.

Leech, G. \& Svartvik, J. (1994).A communicative Grammar of English (2nded.). Longman.

Lyster, R. \& Ranta, L. (1997). Corrective feedback and learner uptake; negotiation of form in communicativeclassroom. Studies in Second Language Acquisition 19, 37-66.

Mackey, A., Gass, S. \& McDonough, K. (2000). How do learners perceive interactional feedback? Studies in

Second Language Acquisition, 22, 471-497.

Mustafa, Z. (2001). Non-Courseware Factors in Using Multimedia in Foreign Language Instruction. Proceedings of the $7^{\text {th }}$ Conference of Pan-Pacific Association of Applied Linguistics, 244-259 [Online].

Norris, J., \& Ortega, L. (2000). Effectiveness of L2 instruction: A research synthesis and quantitative metaanalysis. Language Learning, 50(3), 417-528.

Paulston, C. B., \& Bruder, M. N. (1976). Teaching English as a second language: techniques and procedures. Cambridge, Massachusetts: Winthrop Publishers.

Philp, J. (2003). Constraints on "noticing the gap": Nonnative speakers' noticing of recasts in NS-NNS interaction. Studies in Second Language Acquisition, 25, 99-126.

Pusack, J.P. \& Otto, S.K. (1997). Taking control of multimedia. In M. Bush \& R. Terry (Eds.). Technology-en- hanced language learning (pp.1-46). Chicago: National Textbook Company.

Rahimi, A., \& Dastjerdi, H. (2012). Impact of Immediate and Delayed Error Correction on EFL Learners' Oral

Production: CAF. Mediterranean Journal of Social Sciences. 3(1) 45-54.

Richards, C. \& Schmidt, R. (2002). Dictionary of language teaching and applied linguistics. London: Pearson Education.

Richardson, K., \& Hessey, S. (2009). Archiving the self? Facebook as biography and relational memory. Journal of Information, Communication and Ethics in Society, 7 (1), 25-38.

Sharples, M., Taylor, J., \& Vavoula, G. (2005) towards a theory of mobile learning. Available at: http://www.lsri. nottingham.ac.uk/msh/Papers/Towards $\% 20 \mathrm{a} \% 20$ theory\%20of\%20mobile\%20learning.pdf.

Surakka, K. (2007). Corrective Feedback and Learner Uptake in an EFL Classroom. University of Jyväskylä, Department of Languages [online]. http://urn.fi/ URN: NBN:fi: jyu-2007551. (15 June, 2012).

Swain, M. (1985). Communicative competence: Some roles of comprehensible input and comprehensible output in its development. In Celce-Murcia, M. (Ed.). (2001). Teaching English as a Second or Foreign Language ( $3^{\text {rd }}$ Ed.). New York: Heinle \& Heinle Publishers.

Taipale, P. (2012). Oral Errors, Corrective Feedback and Learner Uptake in an EFL Setting. University of Jyväskylä, Department of Languages [online]: http://urn.fi/URN: NBN:fi: jyu-201203121409. (21 June, 2012).

Warschauer, M., \& Meskill, C. (2000). Technology and second language learning. In J. Rosenthal (Ed.), Handbook of undergraduate second language education (pp. 303-318). Mahwah, New Jersey: Lawrence Erlbaum.

Weigle, S. (2002). Assessing writing. Cambridge: Cambridge University Press. 